\section{ANALISIS KINERJA BADAN PERMUSYAWARATAN DESA (BPD) DALAM MENINGKATKAN PARTISIPASI MASYARAKAT DI BIDANG PEMBANGUNAN INFRASTRUKTUR DESA EMPAKA KEBIAU RAYA KECAMATAN BINJAI HULU KABUPATEN SINTANG Mardawani, Agnesia Hartini, Natalia}

STKIP Persada Khatulitiwa, Studi Pendidikan Pancasila dan Kewarganegaraan, Sintang

\begin{abstract}
Target of in this research for the describe of performance of BPD in improving area society participation development of Countryside infrastructure of Empaka Kebiau Raya, for describe of is way of improving area society participation development of Countryside infrastructure of Empaka Kebiau Raya, for the describe of supplementary factor and resistor of performance of BPD in improving infrastructure area society participation of Countryside of Empaka Kebiau Raya. Method Research which is used in this research isdescriptive qualitative and this research form is case study. Technique data collecting use observation technique, interview, documentation. Result of this research indicate that 1) performance of BPD in improving society participation in the field of development of countryside of Empaka Kebiau Raya low still 2) way of which is done/conducted by BPD in improving participation have been done/conducted as maximum that is by inviting society to got mixed up with activity of development of countryside performed a by government of countryside (BPD), 3) supplementary factor and resistor of its supplementary factor is existence of countryside fund, and its resistor factor is from society itself. Suggestion researcher of BPD expected to earn socialization giving or invite society for deliberation related to program development of countryside..
\end{abstract}

Keyword: performance of BPD, society participation, development 


\begin{abstract}
Abstrak
Tujuan dalam penelitian ini untuk mendeskripsikan kinerja BPDdalam meningkatkan partisipasi masyarakat dibidang pembangunan infrastruktur Desa Empaka Kebiau Raya, untuk mendeskripsikan cara meningkatkan partisipasi masyarakat dibidang pembangunan infrastruktur Desa Empaka Kebiau Raya, untuk mendeskripsikan faktor pendukung dan penghambat kinerja BPD dalam meningkatkan partisipasi masyarakat dibidang infrastruktur Desa Empaka Kebiau Raya. Metode penelitian yang digunakan dalam penelitian ini adalah deskriptif kualitatif dan bentuk penelitian ini adalah studi kasus. Teknik pengumpulan data menggunakan teknik observasi, wawancara, dokumentasi. Hasil penelitian ini menunjukkan bahwa: 1) kinerja BPD dalam meningkatkan partisipasi masyarakat dalam bidang pembanguan desa empaka kebiau raya masih kurang. 2) cara yang dilakukan BPD dalam meningkatkan partisipasi sudah dilakukan dengan semaksimal mungkin yaitu dengan mengajak masyarakat untuk terlibat dalam kegiatan pembangunan desa yang diadakan oleh pemerintah desa (BPD), 3) faktor pendukung dan penghambat faktor pendukungnya adanya dana desa, dan faktor penghambatnya adalah dari masyarakat itu sendiri. Saran peneliti BPD diharapkan dapat memberikan sosialisasi atau mengajak masyarakat untuk musyawarah terkait dengan program pembangunan desa
\end{abstract}

Kata Kunci: Kinerja BPD, partisipasi masyarakat, pembangun. 


\section{PENDAHULUAN}

Berdasarkan Undang Undang Nomor 6 Tahun 2014 Tentang Desa, BPD merupakan Badan Pemusyawaratan ditingkat Desa yang turut membahas dan menyepakati berbagai kebijakan dalam penyelenggaraan Pemerintahan Desa. Sedangkan Suhadi (2007: 77) mengatakan bahwa, Badan Permusyawaratan Desa merupakan lembaga yang lahir atau dibentuk berdasarkan pada ketentuan Undang-Undang Nomor 22 Tahun 1999 Tentang Pemerintah Daerah yang kini telah diubah dengan Undang-Undang Nomor 32 Tahun 2004 Tentang Pemerintah Daerah dengan pembentukan Badan Permusyawaratan Desa diharapkan Pemerintah Desa dapat berjalan secara demokratis, karena itu keberadaan Badan Permusyawaratan Desa dapat dipandang sebagai agen demokratisasi desa.

Sebagai Badan legestaif di tingkat desa sekaligus wakil dari masyarakat, BPD diberi kewenangan penuh untuk menerapkan budaya demokrasi, baik dalam pengawasan terhadap Pemerintah Desa maupun dalam hal meningkatkan partisipasi masyarakat. BPD juga di harapakan menjadi wadah politik bagi masyarakat desa untuk menyampaikan ide atau gagasan mereka agar pembangunan dan kebijakan dapat terealisasi dengan baik.

Pembangungan dan kebijakan dapat terealisasi dengan baik apabila BPD berperan aktif dalam hal pelaksanaan tugas dan fungsinya. Namun fakta yg terjadi, kebanyakan masyrakat di Desa Empaka Kebiua Raya tidak mengetahui tugas dan fungsi BPD terutama dalam hal meningkatkan partisipasi masyarakat di bidang pembangunan desa.

Berdasarkan UU Nomor 6 Tahun 2014 Tentang Desa pasal 55 menyebutkan bahwa Badan Permusyawaratan Desa memiliki fungsi yaitu: (1) membahas dan menyepakati rancangan peraturan desa bersama kepala desa, (2) menampung dan menyalurkan aspirasi masyarakat desa, (3) melakukan pengawasan terhadap kinerja Pemerintahan Desa.

Berdasarkan praobservasi yang dilakukan oleh peneliti pada tanggal 23 Maret 2019, kinerja BPD dalam meningkatkan partisipasi masyarakat di bidang pembangunan Desa Empaka Kebiau Raya masih belum maksimal. Hal ini disebabkan BPD kurang menjalankan tugas dan fungsinya dengan baik. Hal yang membuat partisipasi masyarakat belum maksimal yaitu disebabkan tidak ada sosialisasi dari BPD itu sendiri terkait fungsinya bagi masyarakat dan pemerintahan desa.

Kinerja BPD dinilai belum maksimal. Hal ini ditunjukkan dengan terdapatnya pandangan dari masyarakat yang menganggap Badan Permusyawaratan Desa tidak menjalankan tugas dan fungsinya dengan baik. Aspirasi masyarakat yang di 
tampung oleh BPD belum disampaikan secara maksimal. Hal ini terjadi karena BPD hanya mendengarkan saran dari Kepala Desa dan masyarakat tertent, yang di anggap anggota BPD aktif dalam pembangunan Desa. Padahal pada hakekatnya dalam tujuan membangun suatu desa perlu adanya kerja sama antara pemerintah desa dengan anggota Badan Permusyawaratan Desa dan seluruh masyarakat setempat.

\section{METODE PENELITIAN}

Penelitian ini menggunakan metode penelitian deskriptif dengan bentuk penelitian studi kasus. Teknik pengumpulan data menggunakan teknik observasi, wawancara dan dokumentasi. Menurut Lia dalam Nawawi (2012 : 67) menyatakan bahwa: "metode deskriptif dapat diartikan sebagai prosedur pemecahan masalah yang diselidiki dengan menggambarkan, melukiskan keadaan subjek/objek penelitian (seseorang, lembaga, masyarakat dan lainlain) pada saat sekarang berdasarkan faktafakta yang nampak atau bagaimana seadanya". Subjek penelitian dalam penelitian ini adalah adalah Ketua BPD, Kepala Desa, Sekretaris Desa, Wakil BPD, Sekretaris BPD, Anggota BPD, Kaur Pembangunan, Kaur Ekbang, Kepala Dusun, Ketua RT 4, Ketua Adat, masyarakat di Desa Empaka Kebiau Raya. Sugiyono (2016:218), mengatakan bahwa purposive sampling adalah teknik pengambilan sampel sumber data dengan pertimbangan tertentu. Sebagaimana dinyatakan oleh Nawawi (2012:167) purposive sampling bahwa peneliti menghubungi sampel yang sesuai dengan kriteria-kriteria tertentu yang ditetapkan berdasarkan tujuan penelitian. Berdasarkan kedua pernyataan di atas dalam penelitian ini peneliti melakulkan penarikan sampel menggunakan teknik purposive sampling. Objek penelitian yatiu partisipasi masyarakat di Desa. Penelitian dilaksanakan di Empaka Kebiua Raya Kecamatan Binjai Hulu Kabupaten Sintang.

Data dalam penelitian ini adalah lembar hasil observasi, lembar hasil wawancara dan dokumen-dokumen di Desa Empaka Kebiau Raya. Teknik pengumpulan data menggunakan observasi langsung komunkasi langsung dan dokumentasi.

Alat pengumpulan data mengunakan Lembar Observasi, Lembar Wawancara dan dokumentasi.

\section{HASIL DAN PEMBAHASAN}

\section{A. Hasil Penelitian}

Bedasarkan hasil penelitian yang dilakukan oleh peneliti kinerja BPD dalam meningkatkan partisipasi masyarakat masih sangat rendah. Motivasi yang diberikan oleh Ketua BPD kepada masyarakatnya berupa motivasi pemberian semangat dalam rangka mengikuti kegiatan yang ada di desa. Motivasi tergolong 
menjdi dua bagian yaitu motivasi intrinsik dan motivasi ekstrinsik. Faktor pendukung dan penghambat yaitu dana desa dan masyarat itu sendiri. Hasil penelitian akan peneliti jabarkan sebagai berikut:

1. Kinerja Badan Permusyarwaratan Desa dalam Meningkatkan Partisipasi Masyarakat di Desa Empaka Kebiau Raya.

Berdasarkan hasil wawancara yang peneliti lakukan, kinerja BPD masih belum maksimal karena Ketua BPD masih belum mengetahui tugas dan fungsinya dengan baik dalam lembaga pemerintahan Desa.

2. Cara Meningkatkan Partisipasi Masyarakat di Desa Empaka Kebiau Raya.

Angka partisipasi masyarakat $80 \%$ sudah baik dan $20 \%$ nya lagi masih belum sadar akan pentingnya berpartisipasi dalam suatu pembangunan di desa. Untuk meningkatkan partisipasi masyarakat yang belum mau ikut berpartisipasi maka ketua bpd perlu merubah kinerjanya dari yang sebelumnya yang masih dinilai rendah maka perlu cara atau strategi yang baru yang dapat membuat masyarakat berkeinginan untuk ikut terlibat langsung dalam proses pembangunan yang ada di Desa Empaka Kebiau Raya.
3. Faktor Pendukung dan Penghambat Kinerja BPD dalam Meningkatkan Partisipasi Masyarakat di Desa Empaka Kebiau Raya.

Sebuah pembangunan perlu dilibatkan masyarakat untuk menghidupkan partisipasi masyarakat dalam perencanaan pembangunan. Meskipun partisipasi bukan satusatunya kunci keberhasilan dari pada pencapaian tujuan suatu kegiatan masyarakat bersama dengan pihak lain, tetapi partisipasi mempunyai peran yang penting dalam langkah untuk mencapai tujuan bersama.

\section{Pembahasan}

Pembahasan dalam $\mathrm{p}^{1}$ enelitian terdapat beberapa istilah penting yang digunakan oleh peneliti dalam analisis data. Agar istilah dalam penelitian dapat dipahami maka peneliti mencantumkan istilah sebagai berikut ini.

1. Kinerja BPD dalam meningkatkan pasrtisipasi masyarakat di bidang pembangunan Desa Empaka Kebiau Raya

Kinerja BPD dalam meningkatkan partisipasi masyarakat dibidang 
pembangunan masih rendah. Memang tidak mudah dan butuh proses untuk membangkitkan semangat masyarakat dalam berpartisipasi namun jika ada kemauan pasti ada jalan. Kemudian dalam suatu pembangunan tentunya diperlukan sebuah perencanaan yang sudah dimusyawarah dan telah ditetapkan bersama. Menurut Ruung (2014:11) pembangunan dengan tidak adanya partisipasi masyarakat akan terbengkalai oleh kerana itu perlu langkah dan strategi yang baik dari pemerintah desa agar masyarakat mau ikut berpartisipasi. Dalam hal ini bpd sudah semaksimal mungkin dalam meningkatkan partisipasi dibidang pembangunan desa dengan mendukung semua program-program yang diadakan oleh pemerintah desa dan melibatkan langsung seluruh lapisan masyarakat dalam proses pembangunan desa. Disamping itu juga Soleh (2014:112) menyatakan bahwa dalam pelaksanaan kegiatan pembangunan, partisipasi masyarakat merupakan manifestasi dari kesadaran dan kepedulian serta tanggung jawab terhadap upaya memperbaiki kualitas hidup bersama. Partisipasi masyarakat tersebut cukup luas cakupannya mulai dari proses perencanaan, pelaksanaan, pengawasan, dan pemanfaatan hasil pembangunan. Dalam suatu pembangunan perlu adanya kerja sama yang baik antara pemerintah desa dengan masyarakat karena hal adalah salah satu cara untuk mendorong masyarakat untuk ikut berpartisipasi dalam setiap kegiatan yang diadakan.

2. Cara meningkatkan partisipasi masyarakat di bidang pembangunan Desa Empaka Kebiau Raya

Cara yang dilakukan oleh ketua BPD yaitu berupa motivasi dalam hal pembangunan desa sangat diperlukan dalam rangka menggerakkan masyarakat utnuk ikut berpartisipasi dalam pelaksanaan pembangunan di Desa Empaka Kebiau Raya. Selaku Ketua BPD harus mampu menggerakkan dan mendorong serta memberikan motivasi kepada masyarakat untuk ikut berpartisipasi dalam setia kegiatan yang berhubungan dengan pembangunan, kerana tujuan dari pembangunan itu tidak dapat terwujud apabila tidak ada keterlibatan masyarakat didalamannya. Motivasi yang diberikan oleh KetuaBPD kepada masyarakatnya berupa motivasi pemberian semangat dalam rangka mengikuti kegiatan yang ada di desa. Motivasi tergolong menjdi dua 
bagian yaitu motivasi intrinsik dan motivasi ekstrinsik.

a. Motivasi intrinsik

Motivasi intrinsik adalah motifmotif yang menjadi aktif atau berfungsinya tidak perlu diransang dari luar, karena dalam diri setiap individu sudah ada dorongan untuk melakukan sesuatu. Sardiman dalam Sulistyo (2016:17) motif intrinsik yaitu motif-motif yang menjadi aktif atau berfungsinya tidak perlu diransang dari luar, karena dalam diri setiap individu sudah ada dorongan untuk melakukan sesuatu.

b. Motivasi ekstrinsik

Motivasi ekstrinsik adalah motifmotif yang aktif dan berfungsi karena adanya perangsang dari luar. Motivasi ekstrinsik ini juga penting untuk memotivasi setiap individu agar lebih termotivasi. Cara yang dilakukan oleh pemerintah (BPD) yaitu berkomunikasi yang baik dengan masyarakat karena dengan komunikasi yang baik dapat menumbuhkan keinginan masyarakat untuk ikut berpartisipasi dalam pembangunan desa.
3. Faktor pendukung dan penghambat kinerja BPD dalam menigkatkan partisipasi masyarakat dalam bidang pembangunan Desa Empaka Kebiau Raya

a. Faktor pendukung

Adanya dana desa yang bisa membantu meringankan beban pemerintah desa dan masyarakat. Partisipasi masyarakat dalam proses pembangunan akan terwujud sebagai suatu kegiatan nyata apabila adanya kesadaran, kemampuan dan kesempatan bagi masyarakat untuk berpartisipasi purnomo (2015:103).

b. Faktor penghambat

Faktor penghambat yaitu dari masyarakat itu sendiri yang kurang mau ikut berpartisipasi dalam pembangunan desa. Sebagaimana yang disampaikan oleh Soleh (2014:20) bahwa pembangunan masyarakat tidak memiliki sikap 1). Untuk meninggalkan nilai-nilai lama yang dinilai menghambat perbaikan kualitas hidup, 2). Sika dan tingkat keercayaan kepada pemerintah/penguasa, 3). Sikap untuk selalu ingin lebih maju dari kondisi sekarang atau tidak puas dengan keadaan sekarang, 4). Sikap kebersamaan dalam memecahkan masalah bersama. 


\section{SIMPULAN}

Berdasarkan hasil penelitian dan pembahasan yang telah dikemukakan oleh peneliti yang bersumber dari hasil observasi, wawancara dan dokumentasi mengenai kinerja BPD dalam meningkatkan partispasi masyarakat di bidang pembangunan infrastruktur Desa Empaka Kebiau Raya Kecamatan Binjai Hulu Kabupaten Sintang. Peneliti simpulkan sebagai berikut: 1) Kinerja BPD dalam meningkatkan partispasi masyarakat masih sangat kurang. 2). Cara meningkatkan partisipasi masyarakat dapat dilakukan dengan memberikan motivasi secara intrinsik dan ekstrinsik. 3). Faktor penghambat dan pendukung kinerja BPD dalam meningkatkan partisipasi masyarakat yaitu dana desa dan masyarakat setempat.

\section{DAFTAR PUSTAKA}

Nawawi, Hadari. (2012). Metode Penelitian bidang sosial. Yogyakarta: Gadjah Mada University Press.

Purnomo, A.T.C. (2015). Partisipasi masyarakat dalam perencanaan pembangunan desa wisata limbasari kecamatan bobot sari kabupaten purbalingga. Skripsi. Yogyakarta: Universitas yogyakarta.

Ruung, A. (2014). "Strategi pemerintah desa dalam meningkatkan partisipasi masyarakat terhadappembangunan desa di desa Ammat kecamatan tampan amma kabupaten kepulauan talaud". Skripsi. Manado: Universitas Sam Ratulangi.

Soleh, Chabib. 2014. Dialektika Pembangunan Dengan

Pemberdayaan. Bandung:

Fokusmedia.

Sugiyono. (2016). Metode Penelitian kualitatif kualitatif dan $R \& D$. Bandung: Alfabeta.

Suhadi, 2007. Jurnal Ilmu Hukum-pandecta, hal 77-84. Semarang : Universitas Negeri Semarang.

Sulistyo, I. (2016). Peningkatan motivasi belajar dengan menerapkan model pembelajaran kooperatif TGT Pada pelajaran pkn. Jurnal studi sosial. Volume 4 no. 1 Hal 14-19.

Undang-undang Desa Nomor 6 Tahun 2014 Tentang Desa. 